\title{
Effect of Pragya Yoga and Pranakarshana Pranayama on Self-Concept level of Juvenile Delinquents
}

\author{
Sunil Kumar Deshmukh ${ }^{1 *}$ \\ ${ }^{1}$ Laxmibai National Institute of Physical Education, Gwalior, India \\ *Corresponding author email: drsunilphd@gmail.com \\ https://doi.org/10.36018/dsiij.v17i.186
}

\begin{abstract}
Juvenile delinquency is the result of negative self-concept. Self-concept is essence of personality. To Study the effect of Pragya Yoga and Parnakarshana Pranayama on self-concept level of juvenile delinquents, this prospective study was done on juvenile delinquents of Chhattisgarh, India. For this study, permission was obtained from the superintendent of Juvenile Care Home, Raipur-Chhattisgarh, India. A total hundred (N=100) participants were selected by experimental control group design. 14 to 18 years juvenile delinquents were selected for this study. In this study, to measure self-concept level, the self-concept scale constructed by Dr. R.K Saraswat was used. All participants were divided in two groups, an experimental group $(\mathrm{N}=50)$ and a control group $(\mathrm{N}=50)$. The groups were divided in such a way that there was no statistical significance difference in baseline mean between both the groups before the start of the study. The practice of Pragya Yoga and Pranakarshana Pranayama was done regularly for 45 days by the experimental group. The result showed that Pragyayoga and Pranakarshana Pranayama treatment lead to to significant improvement of self-concept of juvenile delinquents $(\mathrm{p}<0.01)$ indicating utility of these Yogic practices in Juvenile delinquency.
\end{abstract}

Keywords. Pragya Yoga and Pranakarshana Pranayama, Self-concept, Juvenile delinquency

\section{Introduction}

Numerous studies have been done on self-concept that makes it clear that positive self-concept is required for a successful life. Here, positive selfconcept means that the person has a stock of positive thoughts and qualities. Positive and ideal selfconcept makes teenagers a decent citizen and successful human being. The same negative selfconcept leads children to crime. Juvenile delinquency is the result of negative self-concept. Increasing juvenile delinquency is a matter of concern all around the world. Also, in India the growth rate of juvenile crimes has increased to an extremely dangerous level. It has been seen that in the last several years, the number of juvenile crimes has increased rapidly every year. According to the National Crime Record Bureau (NCRB) report 2012, 
crimes involving children have increased from $0.8 \%$ (2001) to $11.8 \%$ (2011). This report also shows the data on juvenile delinquency that children apprehended under both Indian Penal Code (IPC) and Special and Local Law (SLL) has increased from 30,303 (2010) to 33,887(2011) (1).

Numerous research studies have found that there is a significant decrement in emotional stability and selfconcept of child criminals compared to normal adolescents. Due to low self-concept, child criminals are prone to anxiety, frustration, aggression etc. Such children feel themselves different from the main stream of society. Further, these children are leading to crime. To solve this situation Yoga has emerged as an important way to increase selfconcept (2). In a study conducted on 655 adolescents. Author has found that good relationships with parents are more important in adolescents for emotional stability and positive selfconcept. Author studied under the title "SelfConcepts of Rural Early Adolescent Juvenile Delinquents" (3). Using the sample of rural adolescents in this study, it was found that juvenile offenders have a new self-concept than normal adolescents. In a study on "the effect of Yogic practice on self-concept", the author found that yoga develops self-concept of adolescents and brings a lot of positive changes in the lives of teenagers (4). Study on "influence of caste and gender on selfconcept level”, reveals that caste does not have any effect on the self-concept levels in various groups of subjects (5). Self-concept implies the concept of what a person thinks about himself, in which person understands who he is? And what is that? Selfconcept is the 'mirror image' of a person. The self develops by interaction with its environment (6). An experimental study conducted on children with developmental problems shows that yoga has a positive effect on children's social mental intellectual behavioral emotional problems (7).

The development of self-concept occurs as a result of the person's interaction with the society. Often the praise, stories received from other people movies, TV and radio are work as a tool to develop positive self-concept. According to Acharya Shriram Sharma, self-realization means that a man should consider himself as the representative of God and contemplation should excel in character and behaviour. In the present study the effect of yoga science is been studied to evaluate its effect to develop self-concept.

The research study presented has taken the help of yoga science to develop the ideal self-concept. Yoga influences all factors of self-concept such as Identification, Language, Body image, Learning, Feedback etc.

Therefore, yoga is a powerful tool for the development of the self-concept. According to Acharya Sri Mind, intellect and consciousness can be used as a tool to reach in the self. In this research, Pragya Yoga and Pranakarshan Pranayama were coordinated to fulfil these needs. Asanas have been combined with mantras and pranayama on one side in Pragya Yoga. At the same time self-realization meditation has been used to make the contemplation system excellent. Pragya Yoga, as propounded by Acharya Sri, has proved to be an important tool for developing ideal self-concept within juvenile delinquents.

In this research, Pragya Yoga and Pranarshana Pranayama work as independent variable. Pragya yoga is a very good combination of physical, mental and spiritual practices. Pranarshana Pranayama is 
also very simple breathing practice which consist Puraka, Kumbhaka and Rechaka with Pranadharana. The balance of body, mind and spirit can be established by Pragya Yoga and Pranakarshan Pranayama practices. The present study showed how Pragya Yoga and Pranarshana Pranayama are helpful in reducing juvenile delinquents self-concept.

\section{Methodology}

Procedure

This prospective study was done on juvenile delinquents of Chhattisgarh, India. Permission was obtained superintendent of Juvenile care home, ManaDurg, Chhattisgarh. A total hundred ( $\mathrm{N}=100)$ participants were selected by Experimental control group design. 14 to 18 years juvenile delinquents were selected for this study. All participants were divided in two groups. An experimental group $(\mathrm{N}=50)$ and a control group $(\mathrm{N}=50)$. The groups were divided in such a way that there was no statically significance difference in baseline mean IOP between both the groups (data not shown). The practice of Pragya Yoga and Pranakarshan Pranayama were done regularly for 45 days by the experimental group.

After 45 days, the self-concept level of each subject was measured using scale mentioned below. Post measurement of self-concept level for experimental group subjects were taken after allowing practice of Pragya Yoga and Pranakarshan Pranayama daily one hour for 45 days, while the controlled group was not given any practice for 45 days and post data was taken. The daily activities of the control group were kept normal. Whole data was collected after 45 days. The control was unchanged and data not shown. Statistical analysis of the received data was done by t-test.

\section{Self-concept Scale}

In the present study, self-concept levels of juvenile delinquents were measured using self-concept scale constructed by Dr. R.K. Sarswata.

\section{Result}

The result showed that the mean was found to be higher between the self-concept levels of the juvenile delinquents of the experimental group as compared to the mean of the self-concept level of juvenile delinquents of controlled groups. It was clear from the below table, value of ' $\mathrm{t}$ ' was 8.11 which was significant at 0.01 level. Hence the null hypotheses were rejected. The result indicated that the practice of pragya yoga and pranakarshana pranayama has a significant effect on the selfconcept of juvenile delinquents indicating its utility for juvenile delinquents.

\begin{tabular}{|c|c|c|c|c|}
\hline Group & Mean & S.D. & $\begin{array}{c}\mathrm{t}- \\
\text { value }\end{array}$ & $\begin{array}{c}\text { Level of } \\
\text { Significance }\end{array}$ \\
\hline $\begin{array}{c}\text { Control } \\
\text { (No treatment) }\end{array}$ & 171.6 & 21.15 & & \\
\cline { 1 - 2 } $\begin{array}{c}\text { Experiment } \\
\text { (PragyaYog \& } \\
\text { Pranakarshan } \\
\text { Pranayama) }\end{array}$ & 190.1 & 15.85 & 8.11 & 0.01 \\
\hline \multicolumn{2}{|c|}{$\mathrm{N}=100, \mathrm{df}=98$} & & \\
\hline
\end{tabular}

Table.1: Effect of Pragya Yoga and Pranakarshan Pranayama on juvenile delinquents after 45 days. Before the start of Yogic treatment, the control and experimental groups were divided in such a way that there was no statically significance difference in baseline means (data not shown).

\section{Discussion}

In the present research study, to improve the selfconcept level of juvenile delinquents, beautiful coordination of Pragya Yoga and Pranakarshan Pranayama was applied in the patients. In Pragya 
Yoga, Yogasanas are combined with Pranayama. Apart from this, there is also a beautiful coordination of AtmabodhaSadhana (self-realization meditation practice) in Pragya-Yoga. Regular practice of Pragya Yoga and Pranakarshan Pranayama balance the breath and relaxes the mind of the practitioner and they are ready to perform meditation. Self-Realization meditation practice refines thoughts and feelings of juvenile delinquents. Pranakarshan Pranayama helps to free the minds of juvenile delinquents from emotional instability, while self-realization meditation fills them with divine emotions. Pragya Yoga also consists of chanting of the Gayatri Mantra which helps to relieve the stress and depression of the subjects.

In the present research practice of Pragya Yoga and Pranakarshan Pranayama significantly affects to determinants of self such as identification, language, body image, feedback from environment etc. PragyayogaVyayam positively affects to body image. Self realization meditation makes positive to identification of juvenile delinquents. Pranakarshana pranayama develops positive perception and self confidence which helps to develop ideal selfconcept. Chanting the mantra reduces stress levels (8). Repeating the mantra repeatedly by closing the eyes during the mantra chanting affects the entire brain region which affects the body similar to Relaxation Response (9) through this practice there is a decrease in physiological arousal. During this study, they noticed that all the physiological responses were found to be contrary to the 'fight or flight' reaction. Pragya Yoga and Pranakarshana Pranayama play a very important role in balancing the functioning of the sympathetic nerves system.

Western modern science has an opinion that the body's immune system cannot be controlled and promoted (10). It was always thought that we could not voluntarily influence either the immune system or the autonomic nervous system. But research on pranayama and meditation has proved this notion was wrong. The practice of pranayama and meditation affects the hypothalamus, thereby reducing the response to ANS and providing relaxation and peace to the practitioner.

In the research study presented, meditation was done with Gayatri Mantra and Atmabodha - Tattvabodha under PragyaYoga. Mantra chanting consists of four dharnas - learning, retention, recall, recognition, which gives the practitioner introspection, selfdetermination, self-building and self-development. In Pragya yoga practice, instead of concentration, emphasis is placed on the thinking and emotions associated with positive energy. These thoughts and feelings are filled with positivity which affects the inner standard that does the work of autosuggestion which helps in cognitive reconstruction. Pranayama brings control over emotional instability and aggression (10). Pranayama is directly related to the hypothalamus. Pranayama regulates and regulates the functioning of the pituitary gland through the hypothalamus (11), so that possibility of many psychological disorders reduces.

Identifying the wrong thoughts and establishing the right thoughts and feelings in the mind is cognitive restructuring. The same phenomenon applied through Atmbodha-TatvabodhaSadhana (selfawareness meditation) in the present research. Through the meditation, the person becomes aware of all kinds of impulses of good and bad. He gets an opportunity to understand, know his own feelings and is aware of his feelings. This increases the power to recognize one's own potential and reduces negative aspects like self-doubt, anxiety, stress, 
depression and other mental instabilities. However, positive aspects like confidence, optimism, selfdetermination, self-esteem, etc. increase.

\section{Conclusion}

It is clear from the above discussion that the balance of body, mind and spirit can be established by yoga practice. The research presented showed how Pragya Yoga and Pranakarshana Pranayama are helpful in improving self-concept of juvenile delinquents. Practice of Pragya Yoga and Pranakarshan Pranayama significantly affected to determinants of self such as identification, language, body image, feedback from environment etc indicating its utility in improving self-concept not in juvenile but also as broader sense.

\section{References}

1. SahmeyKavita.A Study on Factors Underlying Juvenile Delinquency and Positive Youth, (2013) pp 6. Crimes involving kids go up from $0.8 \%$ to $11.8 \%$ in ten years (2012). Retrieved on 10th December, 2012

http://www.dnaindia.com/india/report_crimes-involving-kidsgo-up-from-0-8pct-to-11-8pct-in-ten-years_1713251

2. Hay I\& Ashman A.F. The Development of Adolescents' Emotional Stability and General Self-Concept: the interplay of parents, peers, and gender, International Journal of Disability, Development and Education,(2003) Volume 50, Number 1, March. https://doi.org/10.1080/1034912032000053359

3. Anthony P. Jurich."Self-Concepts of Rural Early Adolescent Juvenile Delinquents. The Journal of Early Adolescence,(1984)Vol. 4, No. 1, pp41-46 (1984) SAGE Publications. https://doi.org/10.1177/0272431684041005

4. Jadhav, S.G and Havalappanavar, N.B. Impact of Yoga practices on Self-Concept. 5thInt.Con. (dec.28-31,2006), Abstracts compiled and edited T. K Bera and B. R. Sharma, (2006)pp 92. https://doi.org/10.1007/s11614-006-0011-z

5. Gairola, Lata. Caste Affiliation \& Sex Effect on Self-Concept of adolescents, Prachi Journal of Psychho-Cultural Dimensions(2001)., April 2001
6. Rogers, CR.ClientCentered Therapy. Boston:
Houghton.(1951)

7. Kassow, Danielle Z. Effects of Yoga on Young Children With or at Risk for Developmental Disabilities or Delays." BridgesPractice Based Research Synthesis,(2004). Volume 2, Number, 3 August 2004, Page (1-11)

8. Rogers, CR.ClientCentered Therapy. Boston: Houghton.(1951).

9. Crisan, H. G. Pranayama in Anxiety Neurosis -A Pilot study, Heidelberg , University of Heidelberg (1984)

10. Uddupa, KN. Studies on physiological aspects of yoga. In stress and its management by yoga;MotilalBanarasidass. (2000). (pp.47-58), 33, 35, 39, 40-42, \&44(pp-143-161), Delhi

11. Nagendra H.R. Pranayama - The art and science, swami Vivekananda Yoga Snsthana ,Benglore.India. (1999) 